\title{
Хорваты в боях против советских войск под Харьковом осенью 1941 года
}

\author{
Л.Х. Муромцева \\ Воронежский государственный педагогический университет, \\ Россия, 394043, Воронеж, ул. Ленина, 86 \\ E-mail: muromtseva-2020@inbox.ru
}

\begin{abstract}
Аннотация. Одной из первых воинских частей, сформированных в Независимом Государстве Хорватия (существовало в течение 1941-1945 гг.), стал 369-й усиленный хорватский полк. Эта добровольческая часть была отправлена на Восточный фронт, где вошла в состав 100-й легкой пехотной дивизии вермахта. В течение октября - начала ноября 1941 г. хорватские легионеры вели боевые действия на Харьковском направлении против 76-й горно-стрелковой дивизии и других соединений советской 38-й армии. Понеся серьезные потери, хорватские военнослужащие, как свидетельствовали показания перебежчиков и пленных, начали разочаровываться в своем выборе и терять веру в победу нацистской Германии.
\end{abstract}

Ключевые слова: Великая Отечественная война, 369-й усиленный хорватский полк, Харьковская оборонительная операция 1941 года.

Для цитирования: Муромцева Л.Х. 2021. Хорваты в боях против советских войск под Харьковом осенью 1941 года. Via in tempore. История. Политология, 48 (1): 167-176. DOI: $10.52575 / 2687-0967-2021-48-1-167-176$.

\section{Croats in battles against Soviet troops near Kharkov in autumn 1941}

\author{
Ljudmila Kh. Muromtseva \\ Voronezh State Pedagogical University, \\ 86 Lenin St., 394043, Voronezh, Russia, \\ E-mail: muromtseva-2020@inbox.ru
}

\begin{abstract}
One of the first military units formed in the Independent State of Croatia (existed during 1941-1945) was the 369th Reinforced Croatian Regiment. This volunteer unit was sent to the Eastern Front, where it became part of the 100th Light Infantry Division of the Vermacht. During October - early November 1941, Croatian legionnaires fought in the Kharkov direction against the 76th Mountain Rifle Division and other formations of the Soviet 38th Army. The fighting in the first half of October did not lead to a noticeable advance of the Croatian and German units, since the Soviet troops as a whole firmly held the defended line. Only after the directive of the Headquarters on the withdrawal of the troops of the Southwestern Front to the Seversky Donets line, the 38th Army began to withdraw, and the Germans and Croats proceeded to the pursuit operation. The fighting on the eastern bank of the Seversky Donets continued until the beginning of November 1941, after which both opposing sides went over to the defensive and Croatian units were withdrawn to the rear. Having suffered serious losses, Croatian servicemen, as testified by the testimony of defectors and prisoners, began to be disappointed in their choice and to lose faith in the victory of Nazi Germany.
\end{abstract}

Keywords: Great Patriotic War, 369th reinforced Croatian regiment, Kharkov defensive operation 1941.

For citation: Muromtseva L.Kh. 2021. Croats in battles against Soviet troops near Kharkov in autumn 1941. Via in tempore. History and political science, 48 (1): 167-176 (in Russian). DOI: $10.52575 / 2687-0967-2021-48-1-167-176$. 


\section{Введение}

Харьковская (Сумско-Харьковская) оборонительная операция октября 1941 г. не относится к числу наиболее исследованных в отечественной исторической науке операций РККА начального периода Великой Отечественной войны. Об этом, в частности, свидетельствует тот факт, что боевые действия на Харьковском направлении 1-29.10.1941 г. не получили освещения ни в шеститомной «Истории Великой Отечественной войны Советского Союза», ни в двенадцатитомной «Истории Второй мировой войны 1939-1945 гг.», ни в последнем фундаментальном исследовании истории войны - двенадцатитомном издании под эгидой Министерства обороны и под председательством генерала армии С.К. Шойгу «Великая Отечественная война 1941-1945 годов». Между тем Харьковская операция 1941 г. была не самой неудачной среди других операций Красной армии первых месяцев войны. Хотя по ее итогу советские войска были вынуждены оставить Харьков, но не были ни окружены, ни разбиты, и не беспорядочно отступили, а совершили плановый отход в соответствии с приказом Ставки ВГК, после чего перешли к обороне на указанном последнем рубеже Северского Донца, который в дальнейшем прочно удерживали до мая 1942 г., т. е. до второй битвы за Харьков. В результате проведенной оборонительной операции войска левого крыла немецкой группы армий «Юг» были обескровлены и принуждены более чем на полгода остановить наступательные действия, что явилось значимым фактором из числа тех, что в последующем привели к коренному перелому в ходе Великой Отечественной войны и, в конечном счете, к окончательной победе Советского Союза над гитлеровской Германией, ее союзниками и сателлитами.

Относительно последних следует отметить, что в боях октября 1941 г. под Харьковом принимали участие не только немецкие войска; здесь в составе 100 -й легкой пехотной дивизии вермахта вел боевые действия 369-й усиленный хорватский пехотный полк. Эти действия в нашей исторической науке также остаются практически неизученными. В имеющихся статьях по теме [Русак, 2001; Милич, 2005; Романько, 2013] харьковские бои хорватских подразделений не освещены, к тому же в работах последних авторов [Милич, 2005, с. 385; Романько, 2013, с. 75] упоминается о боях, которые хорватские легионеры вели в районах населенных пунктов Петрушаны, Кременчуг, Полтава, Первомайск и др., между тем как на самом деле в ряде из них вела боевые действия 100-я ЛПД еще без 369-го хорватского ПП, а через ряд других 369-й полк только двигался по железной дороге и маршем на фронт. Иная ситуация в зарубежной историографии: и в истории боевого пути 100-й легкопехотной (позднее - егерской) дивизии Х. Нейдхардта [Neidhardt, 1981], и в сравнительно недавно вышедшей 588-страничной монографии А. Обходаса и Дж. Марка, непосредственно посвященной боевым действиям 369-го хорватского полка на Восточном фронте [Obhodas, Mark, 2010], октябрьским 1941 г. боям на Харьковском направлении посвящено по несколько страниц, однако авторы опираются исключительно на немецкие и хорватские источники и излагают события в соответственно хорватской и немецкой перспективе. В связи с этим представляется, что в год восьмидесятилетия Первой битвы за Харьков 1941 года исследование участия в ней войск одного из гитлеровских сателлитов, основанное на анализе архивных документов Центрального архива Министерства обороны РФ с задействованием сравнительно-исторического, проблемно-хронологического методов и метода системного анализа, будет и актуальным, и своевременным.

\section{Хорватские легионеры отправляются на фронт}

369-й усиленный хорватский пехотный полк являлся добровольческой частью, сформированной в Независимом Государстве Хорватия, просуществовавшем с 1941 по 1945 г. в качестве итало-германского протектората под властью ультранационалистического профашистского режима усташей, получившего печальную известность вследствие практиковавшегося им террора и геноцида в отношении этнических меньшинств страны 
[Любомирова И., 2001, с. 179-189; Фрейдзон, 2001, с. 255; Эванс, 2011, с. 178-180; Югославия..., 2011, с. 394-396].

После обучения часть под командованием полковника И. Маркуля в августе 1941 г. была отправлена на Восточный фронт для того, чтобы руководство НГХ (А. Павелич, С. Кватерник) могло продемонстрировать гитлеровской Германии свою лояльность и поддержку [Гальдер, 1971; Семиряга, 2000; Дробязко, Романько, Семенов, 2011; Романько, 2013; Великая Отечественная война..., 2015]. Часть была направлена в 100-ю легкую пехотную дивизию (командир - генерал-лейтенант В. Занне) 55-го армейского корпуса 17-й полевой армии группы армий «Юг». Дивизия считалась легкой, так как была не трех-, а двухполкового состава; усиление ее еще одним полком давало командиру дивизии надежду на более существенные успехи в боевых действиях против частей советской 38-й армии (командующий - генерал-майор В.В. Цыганов) на Харьковском направлении, где данное соединение, несмотря на многочисленные атаки, в течение двух недель с 27 сентября по 10 октября 1941 г., когда к немцам присоединились хорваты, практически не имело продвижения [Мюллер-Гиллебранд, 2002; Романько, 2004; Милич, 2005; Вохмянин, Подопригора, 2008; Вохмянин, Подопригора, 2009].

По прибытии 369-го хорватского полка в 100-ю легкую пехотную дивизию первый был разделен в соответствии с тем, какая немецкая часть отвечала за обучение конкретного хорватского подразделения. 1-й хорватский батальон вместе с 14-й противотанковой ротой был передан под командование 54-го ПП, 2-й батальон - под командование 227-го ПП, артиллерийский дивизион вошел в состав 83-го АП, 11-я самокатная рота - в состав авангарда (Vorausabteilung - передовой отряд); 3-й батальон, полковой штаб и остальные подразделения 369-го ПП составили резерв 100-й ЛПД. Этот порядок был оформлен в приказе командира 100-й ЛПД № 263/41 от 12 октября 1941 г.; вероятно, что немецкое командование не только стремилось повысить уровень подготовки и укрепить дисциплину новой части, но пока что просто не слишком доверяло хорватам. Командиру хорватского полка также не очень понравилось, что его часть фактически перестала быть самостоятельной войсковой единицей, по поводу чего он вступил в переписку с Загребом [Neidhardt, 1981; Русак, 2001; Obhodas, Mark, 2010].

\section{Первая встреча с Красной армией}

Между тем положение на фронте было таково, что хорватским подразделениям практически с первого дня пришлось не только и даже не столько заниматься завершением своей боевой подготовки, сколько принимать непосредственное участие в боевых действиях, будучи используемыми даже не побатальонно, а поротно и повзводно. 10 октября 227-й и 54-й ПП атаковали части 76-й горно-стрелковой дивизии под командованием генерал-майора К.И. Горюнова юго-восточнее Искровки, но продвижения не имели и отошли на исходные позиции. После безуспешной атаки 1-я рота 1-го хорватского батальона была вызвана из резерва и передана под командование 2-го ПБ 54-го ПП, развернувшись между 1-м и 2-м ПБ [Obhodas, Mark, 2010, c. 41] ${ }^{51}$. На следующий день части 100-й ЛПД вместо продолжения атак перешли к обороне, при этом 1-й хорватский батальон был распределен поротно между тремя батальонами 54-го ПП, а две роты 2-го батальона сменили на позициях две роты 227-го ПП. С немецкой стороны действовало несколько усиленных патрулей, в состав которых были включены и хорваты. Хорватской пулеметной ротой, размещенной в Степановке, был сбит советский легкий бомбардировщик, в то же время в ходе советской бомбардировки линии обороны 227-го ПП было убито двое и ранено трое легионеров из состава 8-й роты [Neidhardt, 1981, с. 128; Obhodas, Mark, 2010, c. 41, 45]. 12 октября продолжалось временное затишье, только на правом фланге 76-й ГСД 3-й СБ

${ }^{51}$ Центральный архив Министерства обороны РФ (далее - ЦАМО). Ф. 229. Оп. 161. Д. 177. Л. 44; Ф. 1410. Оп. 1. Д. 17. Л. 187; Ф. 6529. Оп. 0002641 сс. Д. 0007. Л. 53-54. 
434-го СП овладел Пашенков, потеснив 2-й ПБ 54-го ПП; немецкая и хорватская артиллерия из Кочубеевки вела огонь по позициям 93-го ГСП в районе Ровны, который при поддержке 560-го ГАП воспрепятствовал продвижению группы противника, действовавшего с юго-восточной окраины Кочубеевки в направлении правого фланга [Obhodas, Mark, 2010 , с. 54] ${ }^{52}$. На следующий день артиллерийская дуэль продолжалась, 83-й АП 100-й ЛПД с приданными частями 6 артдивизионами (18 батарей) вел огонь по Искровке, но эффект обстрела был незначительным и изменений в положении частей 76-й ГСД не произошло [Obhodas, Mark, 2010, c. 54] ${ }^{53} .14$ октября обмен артиллерийскими ударами продолжился, но дело этим не ограничилось: 434-й СП вновь овладел северо-западной окраиной Пашенков, но был остановлен контратаками перегруппировавшихся немецких и хорватских подразделений (1-й ПБ 369-го ПП) в районе Шелестово, Петропавловка, 137-й ГСП овладел рощей в 1 км юго-западнее ст. Искровка, но также был вынужден отойти назад, а во второй половине дня продолжил наступательные действия силами мелких групп [Neidhardt, 1981, с. 129; Obhodas, Mark, 2010, с. 41] ${ }^{54} .15$ октября правофланговые 434-й СП и 137-й ГСП наступали в прежних направлениях на Петропавловку, Шелестово и Рябковку. Подразделения 54-го ПП и хорватского 1-го ПБ отвечали контратаками, в результате чего хорваты вновь овладели Петропавловкой, потеряв при этом 4 чел. убитыми и 6 ранеными [Neidhardt, 1981, с. 129-130; Obhodas, Mark, 2010, c. 41-43] ${ }^{55}$.

Таким образом, бои в районе Кочубеевки продолжались уже свыше двух недель, и если 76-й ГСД не удалось выполнить поставленную задачу на наступление, то и 100 -я ЛПД, в состав которой был включен 369-й хорватский ПП, с 27 сентября по 15 октября 1941 г. фактически не смогла продвинуться вперед. Однако на правом фланге 38-й и левом фланге 21-й армий Юго-Западного фронта к середине октября сложилась опасная ситуация: противник активно продвигался на Богодуховском направлении, так что линия фронта первой стала представлять собой оперативный выступ, грозивший превратиться в «мешок». Более того, активные наступательные действия противника против войск соседних Брянского и Южного фронтов привели к тому, что в полуохвате с флангов оказался ЮЗФ в целом. Чтобы избежать риска возможного удара подвижных войск противника с флангов и прорыва их в тыл, а также с целью спрямления и сокращения линии фронта, Ставкой было принято решение об отводе войск ЮЗФ (и, соответственно, правофланговой 12-й армии ЮФ, подчиняемого с 16.10.1941 г. ЮЗФ) на новую линию обороны. Директивой № 003010 от 15.10.1941 г. фронту была поставлена задача в период с 17 по 30 октября отвести войска на линию Касторное, Старый Оскол, Новый Оскол, Валуйки, Купянск, Лиман, после чего вывести в резерв 6 стрелковых дивизий и 2 кавкорпуса [Баграмян, 1971, с. 385-388; Русский архив..., 1996, с. 245].

\section{От Перекопа до Северского Донца: бои и потери}

Из-за прорыва немецкой 1-й танковой армии на Ростовском направлении отвод войск ЮЗФ начался на сутки раньше. Командир 76-й ГСД приказом № 04 от 4.00 16.10.1941 г. поставил перед частями задачу, прикрываясь арьергардами (батальон от 434-го СП и по стрелковой роте от 137-го, 216-го и 93-го ГСП), отойти на промежуточный рубеж: (иск.) х. Дергачи, Перекоп, (иск.) Снежков Кут ${ }^{56}$. К исходу дня части дивизии были отведены на новый рубеж и заняли позицию между 212-й СД и 47-й ГСД в полосе: свх. Перебудова, свх. южнее железной дороги Высокополье - Ковяги, 500 м западнее Перекоп, к. Левендало, х. Илюховка, х. Контакузово, х. Корсуновка ${ }^{57}$. Установив разными видами разведки

${ }^{52}$ ЦАМО. Ф. 1410. Оп. 1. Д. 17. Л. 187; Ф. 6529. Оп. 0002641 сс. Д. 0007. Л. 58.

${ }^{53}$ ЦАМО. Ф. 229. Оп. 161. Д. 177. Л. 57; Ф. 6529. Оп. 0002641 сс. Д. 0007. Л. 60.

54 Там же. Л. 61.

55 Там же. Л. 66.

56 Там же. Л. 66.

${ }^{57}$ ЦАМО. Ф. 229. Оп. 161. Д. 177. Л. 65; Ф. 6529. Оп. 0002641 сс. Д. 0007. Л. 67. 
отход советских войск, противник перешел к преследованию. В 15.00 подразделения 54-го ПП, в том числе 1-й хорватский ПБ, начали выдвижение к ст. Коломак, 227-го ПП со 2-м хорватским ПБ - к ст. Искровка. Через п. Коломак отходили на восток 137-й и 216-й ГСП, арьергард занял позицию в Белоусове. К исходу дня обе станции были заняты противником, а утром 17 октября 1-й хорватский ПБ атаковал арьергард 76-й ГСД, отошедший на восточный берег р. Коломак. Мост через реку был взорван, но хорваты сумели переправиться и оттеснить советскую пехоту, после чего саперный батальон 100-й ЛПД вместе с хорватским саперным взводом укрепили оставшийся неповрежденным другой мост и противник продолжил преследование. Вперед был выдвинут авангард, в состав которого вошли подразделения дивизионного разведбата, роты самокатчиков немецких и хорватского полков, саперные и противотанковые подразделения [Neidhardt, 1981, с. 131-132; Obhodas, Mark, 2010, c. 43, 45, 49, 55] ${ }^{58}$.

В 12.0017 октября штаб 76-й ГСД сообщал в штаб 38-й армии о занятии рубежа, проведении окопных работ и о том, что «противник активных действий не проявляет (полное затишье)» ${ }^{59}$. Однако затишье продолжалось недолго: в 14.00 противник открыл артиллерийский огонь из Высокополья по позициям 434-го СП, затем огонь открыли подошедшие к переднему краю немецкие танки, в результате чего полк оставил свх. Перебудово и отошел на юг к высоте $156,3^{60}$. В то же время у немцев и хорватов дела обстояли немногим лучше: авангард 100-й ЛПД, двигаясь по дороге на Валки, в районе Бровкивка попал под огонь советской артиллерии. Хорватская 11-я рота была отправлена на разведку по северному ответвлению дороги в направлении Перекоп, где попала под огонь всех видов оружия 216-го и 137-го ГСП, поддерживаемых взводом 100-го ПТБ и двумя танками, была прижата к земле и только с наступлением темноты смогла отойти в лес у развилки дорог; потери составили 6 чел. убитыми, в т. ч. 1 офицер, и 20 ранеными [Neidhardt, 1981, c. 132; Obhodas, Mark, 2010, c. 49-50]. На следующий день в районе Ковяги, Перекоп, Илюховка, Контакузово разгорелись ожесточенные бои. 54-й ПП наступал на позиции 76-й ГСД на левом фланге, 227-й ПП - на правом фланге. Под прикрытием тумана, используя поддержку не только полевой, но и самоходной артиллерии 197-го дивизиона штурмовых орудий, подразделения 227-го ПП атаковали оборону 216-го ГСП между Перекопом и Илюховкой. Наступающие оказались под огнем гаубиц 560-го ГАП из Контакузово, понесли потери и на время остановились (216-м ГСП были захвачены трофеи: пулеметы, автоматы, винтовки и др.), но через некоторое время прорвались в глубину обороны полка и вышли с фланга в район огневой позиции 3-й батареи, командир и бойцы которой не отступили, приняли бой и, защищаясь до последнего, к 21.00 героически погибли в полном составе вместе с командиром и комиссаром. Артполк по приказу командира дивизии в ночь на 19 октября продолжил отход в район Буды, тогда как стрелковые части арьергардами продолжали удерживать рубеж до вечера 19.10.1941 г. (основные силы получили приказ на отход в район Березовое, Буды, Южный). 227-й ПП вместе с хорватскими подразделениями наступал через Илюховку в направлении Валки, 54-й ПП с 1-м и 2-м хорватскими батальонами с боем овладел Перекопом, защищаемым 137-м ГСП ${ }^{61}$. Этот бой дорого обошелся хорватам: 1-й и 2-й батальоны потеряли 17 чел. убитыми (в т. ч. 1 офицер и 2 унтер-офицера), 18 чел. ранеными (в т. ч. 1 офицер и 3 унтер-офицера) и 40 чел. пропавшими без вести (в т. ч. 1 унтер-офицер). Трое хорватских военнослужащих по результатам боя были награждены Железными крестами 2-го класса; как нетрудно заметить, деревянных крестов в тот день оказалось больше [Neidhardt, 1981, с. 133-134; Мельников, 2008, с. 125; Obhodas, Mark, 2010, c. 44, 48].

207-й ГСП и за ним 434-й СП отходили через Ковяги и Люботин на Березовое и Буду, 137-й и 98-й ГСП - через Валки на Буду, 216-й ГСП - через Валки на Южный; части

58 Там же. Л. 67.

${ }^{59}$ ЦАМО. Ф. 393. Оп. 0008973. Д. 0043. Л. 191.

${ }^{60}$ Там же. Л. 186-187.

${ }^{61}$ ЦАМО. Ф. 1163. Оп. 1. Д. 11. Л. 15; Д. 251. Л. 177; Ф. 6529. Оп. 0002641 сс. Д. 0007. Л. 68; Ф. 11598. Оп. 0000001. Д. 0001. Л. 8. 
двигались по покрытым осенней грязью разбитым дорогам, подвергаясь ударам немецкой авиации. Сосредоточившись в указанных районах, 76-я ГСД уже утром 20 октября по приказу командования была в качестве армейского резерва отправлена маршем в северном направлении на Гавриловку, Пересечное, Полевое с целью усиления правого фланга 38-й армии, прикрывавшего Харьков с северо-запада, где наступала 101-я ЛПД, в то время как 57-я ПД действовала фронтально с запада, а 100-я ЛПД обходила город с юго-запада. Отход на восток и дальнейшее движение на север 76-й ГСД прикрывали с запада 300-я СД и с юга 47-я ГСД [Русский архив..., с. 251] ${ }^{62}$.

После овладения Перекопом части 100-й ЛПД, ведя бои с арьергардами 300-й СД, двинулись на Валки и далее на Одрынку. 1-й хорватский ПБ двигался во втором эшелоне 54-го ПП, 2-й ПБ - с 227-м ПП, в маршевой колонне которого шел и отделенный 18.10.1941 г. от 83-го АП хорватский артдивизион после того, как поддержал огнем атаки свои войска при Перекопе. (Из-за истощения тягловой силы - 233 лошади вышли из строя - дивизион, потерявший за предшествующие дни двух человек пропавшими без вести и одиннадцать дезертировавшими, остановился на отдых в Валки и в дальнейших боях за Харьков участия не принимал.) Штаб 369-го ПП с 3-м ПБ двигались в дивизионном резерве. 20-21 октября части дивизии, не встречая существенного сопротивления отходящих 300-й СД и 47-й ГСД, достигли Караван, овладели Буда, подошли к Березовое (участок 300-й СД) и завязали бой за Мерефу (участок 47-й ГСД). Авангард 100-й ЛПД, включая хорватских самокатчиков, во взаимодействии с частями 57-й ПД занял Коротич, вступив здесь в бой с находившимися на марше частями 76-й ГСД, и двинулся в направлении Липовой Рощи и Филиппово, где в районе ст. Рыжов столкнулся с обороной 647-го СП только что сформированной 216-й СД, которая вместе с 57-й СБР НКВД в качестве гарнизона Харькова получила приказ удерживать город до 25 октября. Бой здесь окончился без явного преимущества с той и другой стороны, обе понесли потери и вернулись на исходные позиции (по отправленному в этот день рапорту штаба дивизии с момента пересечения Днепра потери 100-й ЛПД составили 1746 чел.) [Баграмян, 1971, с. 393-394; Neidhardt, 1981, c. 134-137; Obhodas, Mark, 2010, c. 44, 49, 51-52, 55] ${ }^{63}$.

22 октября 1941 г. бои на юго-западной окраине Харькова продолжались. Авангард и 54-й ПП 100-й ЛПД овладел Липовой Рощей (при этом 1-й хорватский ПБ имел боестолкновение в районе Высокого) и вел бой с частями 216-й СД за Филиппово; 227-й ПП занял Березовку и Покотиловку, где оборонялись остатки 300-й СД. Бои за Филиппово с участием хорватских подразделений дивизионного авангарда продолжались до 24 октября, после чего 54-й ПП был выведен в Липовую Рощу, а хорватский 1-й ПБ - в Ледное, оставаясь там до 28 октября, после чего был передислоцирован в Лосево, где соединился с другими подразделениями 369-го ПП (только хорватский саперный взвод вместе с саперным батальоном 100-й ЛПД продолжал работы по ремонту мостов, созданию переправ и разминированию до 22 ноября, только после чего присоединился к полку). 2-й ПБ был выведен с фронта 25 октября, когда части 57-й ПД окончательно овладели Харьковом, а войска 38-й армии начали отход через промежуточные рубежи по р. Рогань и р. Студеная на рубеж Северского Донца. 11-я самокатная рота в составе дивизионного авангарда участвовала в зачистке южной и юго-восточной окраин Харькова, где 26 октября имела боестолкновение в районе х. Федорцы. 216-я, 300-я, 199-я сд и 47-я ГСД отходили на Рогань и Каменную Яругу, по этой оси 27-28 октября двигался и авангард 100-й ЛПД (28.10.1941 г. дивизия была включена в состав 11-го АК 6-й армии генерал-фельдмаршала В. фон Рейхенау). В районе Каменной Яруги 29.10.1941 г. 11-я хорватская рота имела еще один бой, а 30 октября достигла Чугуева,

62 ЦАМО. Ф. 229. Оп. 161. Д. 177. Л. 72; Ф. 6529. Оп. 0002641 сс. Д. 0007. Л. 68; Ф. 11598. Оп. 0000001. Д. 0001. Л. 8.

${ }^{63}$ ЦАМО. Ф. 229. Оп. 161. Д. 80. Л. 29; Д. 177. Л. 79; Ф. 11598. Оп. 0000001. Д. 0001. Л. 9. 
обороняемого частями 47-й ГСД; авангард 100-й ЛПД, наступая вдоль железной дороги и шоссе, овладел городом [Obhodas, Mark, 2010, c. 55] ${ }^{64}$.

Таким образом, 100-я ЛПД к концу октября 1941 г. своим авангардом вышла к Северскому Донцу, откуда хорватская рота была возвращена в состав 369-го полка. На этом рубеже наступление левого крыла группы армий «Юг» вследствие понесенных потерь, трудностей со снабжением и возросшим сопротивлением советских войск остановилось. (По предложению командования ЮЗФ Ставка утвердила новый рубеж обороны фронта восточнее прежде намеченной линии, чтобы прикрыть железнодорожную магистраль Касторное - Валуйки - Купянск - Лисичанск; новая линия, обозначенная в приказе штаба ЮЗФ № 0244/оп от 28.10 .1941 г., проходила через Тим, Изюм и по Северскому Донцу до Ямполь) [Баграмян, с. 401-405; Русский архив..., 1996, с. 265; Obhodas, Mark, 2010, с. 53-54] ${ }^{65}$.

Разведывательные рейды подразделений дивизионного авангарда на восточном берегу Северского Донца, где они имели боестолкновения с частями 47-й ГСД и 199-й СД, продолжались в начале ноября 1941 г. 47-я ГСД занимала позиции по восточному берегу реки Б. Бурлук от Шиповатово до Новоивановки, 199-я СД - южнее: (иск.) Новоивановка, (иск.) Балаклейка. Между советскими и немецкими позициями тем самым образовалась довольно широкая ничейная полоса, и обе стороны высылали навстречу друг другу разведывательные партии, а в дальнейшем и усиленные отряды, завязывавшие бои друг с другом в районах Граково, Гавриловка, Василенково, Коробочкино, Малиновка, Анновка, Печенеги. В течение второй декады ноября происходили довольно серьезные бои за Граково и Анновку между 617-м СП 199-й СД и 148-м ГСП 47-й ГСД и противником, в ходе которых населенные пункты не раз переходили из рук в руки. Советские части захватили 15 пленных и трофеи: 8 орудий, 4 миномета, 15 станковых и 9 ручных пулеметов, 30 винтовок, 1 радиостанцию, 4 повозки, 59 лошадей и другое военное имущество. Правда, их противником были части уже не 100-й ЛПД, а принявшей ее участок 297-й ПД (524-й ПП); первая (собственно, дивизионный авангард) 10.11.1941 г. была отведена за линию фронта [Neidhardt, 1981, с. 144] ${ }^{66}$.

\section{Хорваты в тылу и в плену}

Части 100-й ЛПД были разбросанно расквартированы в Каменной Яруге, Рогани, Лосево, Харькове, Осмово и Боровом, занимаясь приведением в порядок вооружения, автомобильного и гужевого транспорта, тренировками личного состава, а также - между делом - грабежом гражданского населения. (Хорват-перебежчик С. Зимович на допросе 2.12.1941 г. рассказывал: «В г. Харькове немцы забирают хлеб, одежду и другие вещи, я видел, когда немцы на улице снимали с местного гражданина сапоги. Я в г. Харькове на Проспекте Сталина № 175 стоял на квартире у работницы Гущиной Надежды Андреевны. Она рассказывала, что у нее немцы забрали одежду, рубашки, платки, мыло, сахар и запасы хлеба вплоть до того, что забрали тесто, приготовленное для выпечки хлеба» ${ }^{67}$.) Партизаны и подпольщики отвечали оккупантам нападениями и диверсиями, уничтожая вражеских солдат, офицеров и даже генералов (14.12.1941 г. в Харькове был взорван командир 68-й ПД генерал-майор Г. Браун с несколькими офицерами своего штаба), те, в свою очередь, проводили массовые аресты заложников и казни [Neidhardt, 1981, с. 145] ${ }^{68}$.

${ }^{64}$ ЦАМО. Ф. 229. Оп. 161. Д. 177. Л. 97-98.

${ }^{65}$ ЦАМО. Ф. 229. Оп. 161. Д. 46. Л. 40-42; Оп. 161. Д. 15. Л. 5; Д. 46. Л. 293-296, 354; Д. 155. Л. 119, 214; Д. 177. Л. 84, 87, 97; Д. 119. Л. 411-412; Ф. 7712. Оп. 217866 с. Д. 1. Л. 98-99; Ф. 7712. Оп. 217866 с. Д. 1. Л. 98-99.

${ }^{66}$ ЦАМО. Ф. 229. Оп. 1. Д. 178. Л. 2, 3, 8, 9, 12, 13, 18, 21, 23, 25, 27, 29, 31, 33; Оп. 161. Д. 37. Л. 241; Д. 47, Л. 155, 331, 383; Д. 48. Л. 118-122; Ф. 11247. Оп. 0000001. Д. 0005. Л. 393.

${ }^{67}$ ЦАМО. Ф. 32. Оп. 11306. Д. 22. Л. 89.

${ }^{68}$ Там же. Л. 89. 
Хорватское подразделение из состава дивизионного авангарда было снято с фронта еще 5 ноября 1941 г. На следующий день генерал В. Занне издал приказ о возобновлении подготовки личного состава 369-го хорватского полка под руководством немецких офицеров и инструкторов. Хотя с 10 ноября общее руководство обучением было возложено на командира полка оберста И. Маркуля, на деле всем процессом распоряжались немцы во главе с оберст-лейтенантом А. Тьером. В каждую хорватскую роту для наблюдения за обучением были введены немецкие офицер, унтер-офицер и солдат, к полковому и батальонным штабам были прикомандированы военные чиновники, переводчики, медики и технические специалисты. По мнению немецкой стороны, значительная часть хорватских офицеров и унтер-офицеров все еще не соответствовали предъявляемым требованиям [Neidhardt, 1981, c. 142-143; Obhodas, Mark, 2010, c. 57-60].

Согласно официальным данным на 15 ноября, за время участия в боевых действиях хорватская часть потеряла 37 чел. убитыми, 76 ранеными и 52 пропавшими без вести, и к 21.11.1941 г. численность полка составляла 104 офицера, 5 военных чиновников, 495 унтерофицеров и 3185 солдат, всего 3799 чел. Эта цифра объяснялась тем, что из Дёллерсхайма на фронт полк отбыл со сверхштатной численностью, что впоследствии подтверждали хорватские перебежчики и военнопленные. (Так, солдат Н. Янжек показывал, что на советскогерманский фронт отправилось около 5000 чел., но до позиций добралось около 4000 чел., так как примерно 800 чел. по разным причинам отсеялись по пути, а около 200 чел. были отправлены из Харькова по решению военно-полевого суда в Германию; последний факт подтверждал и унтер-офицер С. Зимонич.) В любом случае, первый опыт сражений против Красной армии, полученный хорватскими легионерами в октябрьских боях на Харьковском направлении, сильно отличался от изначальных надежд на быструю и легкую военную прогулку. Относительно теплая украинская зима и сравнительно комфортабельные условия, в которых хорваты находились в период ноябрьского обучения в Лосево, казались им чересчур жесткими. Впрочем, до какой-то степени так оно и было: пленные свидетельствовали, что хорватские солдаты не имели зимнего обмундирования и получали не более 300 г хлеба, причем бывали случаи, что хлеба не получали в течение четырех дней. Соответственно, если в первые недели войны легионеры под влиянием немецкой пропаганды, в силу нахождения в тылу, хорошего питания и незначительности трудностей не проявляли недовольства и верили в победу немцев, то к зиме 1941 г. их настроение изменилось. По словам перебежчика Зимонича, в Харькове одни хорватский унтер-офицер бежал из части, переодевшись в гражданскую одежду, но был пойман и расстрелян; военнопленный И. Маленица, фельдфебель 4-й роты (пулеметной) 369-го ПП, рассказывал, что в его роте во время пребывания в Харькове застрелился унтер-офицер Ниджие Муйкович. Зимонич свидетельствовал, что ему часто приходилось слышать среди солдат, что они воюют не за себя, а за чужие интересы, и такое же настроение было среди офицеров, которые говорили, что воевать не за что, и это при том, что в войсках было развито доносительство, и если в артдивизионе арестовали 4 чел., то в пехотных подразделениях - 180 чел.; солдат отдавали под суд и осуждали на срок от 5 месяцев до 2 лет. «Мое отношение к войне Германии против Советского Союза такое, что я пошел бы бить немцев», - заявлял перебежчик ${ }^{69}$.

\section{Заключение}

Подводя итоги исследования, следует сказать, что боевые действия 369-го усиленного хорватского пехотного полка в боях против советских войск на Харьковском направлении в октябре 1941 г. имели большое значение не столько для последних, сколько для самих хорватских легионеров. Хорваты участвовали в боях мелкими подразделениями в составе немецких частей, и боевая эффективность этих подразделений была по этой причине незначительной. В то же время первые боестолкновения с частями Красной армии,

${ }^{69}$ ЦАМО. Ф. 32. Оп. 11306. Д. 22. Л. 88-89; Ф. 228. Оп. 709. Д. 535. Л. 21-22, 25, 45 об. 
первые понесенные в них потери, первые сложности со снабжением в условиях русского климата произвели сильное впечатление на хорватских добровольцев. Приведенные высказывания перебежчиков и пленных хорошо иллюстрируют перемену настроения хорватских военнослужащих, ставшую следствием первых более-менее серьезных боев на Восточном фронте, а впереди их было еще очень много...

\section{Список литературы}

1. Баграмян И.Х. 1971. Так начиналась война. М., Воениздат, 512.

2. Великая Отечественная война 1941-1945 годов: в 12 т. 2015. Т. 1. Основные события войны. М., Кучково поле, 976.

3. Вохмянин В.К., Подопригора А.И. 2008. Харьков, 1941. Часть 1. У края грозы. Харьков, Райдер, 100.

4. Вохмянин В.К., Подопригора А.И. 2009. Харьков, 1941. Часть 2. Город в огне. Харьков, Райдер, 148.

5. Гальдер Ф. 1971. Военный дневник. Ежедневные записи начальника Генерального штаба Сухопутных войск 1939-1942 гг. Том III. От начала восточной кампании до наступления на Сталинград (22.06.1941-24.09.1942). М., Воениздат, 367.

6. Дробязко С.И., Романько О.В., Семенов К.К. 2011. Иностранные формирования Третьего рейха. М., АСТ, Астрель, 830.

7. Мельников В.М. 2008. Харьков в огне сражений: «Забытый» 41-й. Харьков, СИМ, 523.

8. Милич А. 2005. Хорватские добровольцы в германском вермахте во Второй мировой войне. Крестовый поход на Россию. М., Яуза, 480.

800.

9. Мюллер-Гиллебранд Б. 2002. Сухопутная армия Германии 1933-1945 гг. М., Изографус,

10. Романько О.В. 2004. Мусульманские легионы во Второй мировой войне. М., АСТ, Транзиткнига, 312.

11. Романько О.В. 2013. Хорватские добровольческие формирования на советскогерманском фронте (1941-1943). Военно-исторический архив, 9: 71-90.

12. Русский архив: Великая Отечественная: Ставка ВГК. Документы и материалы. 1941 год. 1996. Т. 16 (5-1). М., Терра, 448.

13. Семиряга М.И. 2000. Коллаборационизм. Природа, типология и проявления в годы Второй мировой войны. М., РОССПЭН, 863.

14. Фрейдзон В.И. 2001. История Хорватии. Краткий очерк с древнейших времен до образования республики (1991 г.). СПб., Алетейя, 318.

15. Эванс Р. 2011. Третий рейх. Дни войны. 1939-1945. М., Астрель, 942.

16. Югославия в XX веке: Очерки политической истории. 2011. М., Индрик, 888.

17. Любомирова И. 2001. Национализъм и национална политика в Независимата Хърватска Държава (1941-1945). София, С. Климент Охридски, 501.

18. Neidhardt H. 1981. Mit Tanne und Eichenlaub. Kriegschronik der 100. Jäger-Division, vormals 100 leichte Infanterie-Division. Graz, Stocker-Verlag, 468.

19. Русак А.В. 2001. Хорватські легіонери на Східному фронті 1941-1943 рр. Український історичний журнал, 2: 112-121.

20. Obhodas A., Mark J. 2010. Croatian Legion The 369th Reinforced (Croatian) Infantry Regiment on the Eastern Front 1941-1943. Sydney, Leaping Horseman Books, 600.

\section{Referenses}

1. Bagramyan I.Kh. 1971. Tak nachinalas' voyna [This is how the war began]. Moscow, Publ. Voenizdat, 512 (in Russian).

2. Velikaya Otechestvennaya voyna 1941-1945 godov: v 12 t. 2015. T. 1. Osnovnye sobytiya voyny [The Great Patriotic War of 1941-1945: in 12 volumes. Vol. 1. The main events of the war]. Moscow, Publ. Kuchkovo pole, 976 (in Russian).

3. Vokhmyanin V.K., Podoprigora A.I. 2008. Khar'kov, 1941. Chast' 1. U kraya grozy [Kharkov, 1941. Part 1. At the edge of a thunderstorm]. Khar'kov, Publ. Rayder, 100 (in Russian). 
4. Vokhmyanin V.K., Podoprigora A.I. 2009. Khar'kov, 1941. Chast' 2. Gorod v ogne [Kharkov, 1941. Part 2. City on fire]. Khar'kov, Publ. Rayder, 148 (in Russian).

5. Gal'der F. 1971. Voennyy dnevnik. Ezhednevnye zapisi nachal'nika General'nogo shtaba Sukhoputnykh voysk 1939-1942 gg. Tom III. Ot nachala vostochnoy kampanii do nastupleniya na Stalingrad (22.06.1941-24.09.1942) [War diary. Daily notes of the Chief of the General Staff of the Land Forces 1939-1942. Volume III. From the beginning of the eastern campaign to the offensive on Stalingrad (06/22/1941-09/24/1942)]. Moscow, Publ. Voenizdat, 367.

6. Drobyazko S.I., Roman'ko O.V., Semenov K.K. 2011. Inostrannye formirovaniya Tret'ego reykha [Foreign formations of the Third Reich]. Moscow, Publ. AST, Astrel', 830 (in Russian).

7. Mel'nikov V.M. 2008. Khar'kov v ogne srazheniy: «Zabytyy» 41-y [Kharkov in the fire of battles: «Forgotten» 41st]. Khar'kov, Publ. SIM, 523 (in Russian).

8. Milich A. 2005. Khorvatskie dobrovol'tsy v germanskom vermakhte vo Vtoroy mirovoy voyne. Krestovyy pokhod na Rossiyu [Croatian volunteers in the German Wehrmacht in World War II. Crusade to Russia]. Moscow, Publ. Yauza, 480 (in Russian).

9. Myuller-Gillebrand B. 2002. Sukhoputnaya armiya Germanii 1933-1945 gg. [The German Land Army 1933-1945]. Moscow, Publ. Izografus, 800.

10. Roman'ko O.V. 2004. Musul'manskie legiony vo Vtoroy mirovoy voyne [Muslim legions in World War II]. Moscow, Publ. AST, Tranzitkniga, 312 (in Russian).

11. Roman'ko O.V. 2013. Khorvatskie dobrovol'cheskie formirovaniya na sovetsko-germanskom fronte (1941-1943) [Croatian volunteer formations on the Soviet-German front (1941-1943)]. Voennoistoricheskiy arkhiv, 9: 71-90 (in Russian).

12. Russkiy arkhiv: Velikaya Otechestvennaya: Stavka VGK. Dokumenty i materialy. 1941 god [Russian archive: Great Patriotic War: Supreme Command Headquarters. Documents and materials. 1941 year.]. 1996. T. 16 (5-1). Moscow, Publ. Terra, 448 (in Russian).

13. Semiryaga M.I. 2000. Kollaboratsionizm. Priroda, tipologiya i proyavleniya v gody Vtoroy mirovoy voyny [Collaboration. Nature, typology and manifestations during the Second World War]. Moscow, Publ. ROSSPEN, 863 (in Russian).

14. Freydzon V.I. 2001. Istoriya Khorvatii. Kratkiy ocherk s drevneyshikh vremen do obrazovaniya respubliki (1991 g.) [History of Croatia. A brief sketch from ancient times to the formation of the republic (1991)]. Saint Petersburg, Publ. Aleteyya, 318 (in Russian).

15. Evans R. 2011. Tretiy reykh. Dni voyny. 1939-1945 [Third Reich. Days of war. 1939-1945]. Moscow, Publ. Astrel', 942.

16. Yugoslaviya $\mathrm{v} \mathrm{XX}$ veke: Ocherki politicheskoy istorii [Yugoslavia in the 20th Century: Essays on Political History]. 2011. Moscow, Publ. Indrik, 888 (in Russian).

17. Любомирова И. 2001. Национализъм и национална политика в Независимата Хърватска Държава (1941-1945). София, Publ. С. Климент Охридски, 501.

18. Neidhardt H. 1981. Mit Tanne und Eichenlaub. Kriegschronik der 100. Jäger-Division, vormals 100 leichte Infanterie-Division. Graz, Publ. Stocker-Verlag, 468.

19. Русак А.В. 2001. Хорватські легіонери на Східному фронті 1941-1943 рр. Український історичний журнал, 2: 112-121.

20. Obhodas A., Mark J. 2010. Croatian Legion The 369th Reinforced (Croatian) Infantry Regiment on the Eastern Front 1941-1943. Sydney, Publ. Leaping Horseman Books, 600.

\section{ИНФОРМАЦИЯ ОБ АВТОРЕ}

Муромцева Людмила Халиловна, экстерн Воронежского государственного педагогического университета, г. Воронеж, Россия

\section{INFORMATION ABOUT THE AUTHOR}

Ljudmila Kh. Muromtseva, extern of the Voronezh State Pedagogical University, Voronezh, Russia 